\title{
Coleoptera Larval Fauna Associated with Termite Nests (Isoptera) with Emphasis on the "Bioluminescent Termite Nests" from Central Brazil
}

\author{
Cleide Costa $^{1}$ and Sergio Antonio Vanin ${ }^{2}$ \\ ${ }^{1}$ Museu de Zoologia, Universidade de São Paulo, Avenida Nazaré 481, 04263-000 São Paulo, Brazil \\ ${ }^{2}$ Departamento de Zoologia, Instituto de Biociências, Universidade de São Paulo, Rua do Matão, \\ Travessa 14, 101, 05508-900 São Paulo, Brazil \\ Correspondence should be addressed to Cleide Costa, cleideco@usp.br \\ Received 1 February 2010; Accepted 5 May 2010 \\ Academic Editor: Michael Rust
}

Copyright (C) 2010 C. Costa and S. A. Vanin. This is an open access article distributed under the Creative Commons Attribution License, which permits unrestricted use, distribution, and reproduction in any medium, provided the original work is properly cited.

Beetle larvae that inhabit termite nests present modifications that allow them to cohabitate with the termites. Some are physogastric and bear special glands and different setae all over their bodies, whereas others are not physogastric. Both kinds of larvae may be termite predators. Some species usually live in the nest cabbage pan, feeding on organic matter, mushrooms, and excrements or eating the nest walls and sometimes causing the nest to be destroyed. Other species live in superficial galleries of the nest and feed on preys that live outside. However, all interactions between these inquilines beetles and their termite hosts are very complex and still little understood. Emphasis was done to the bioluminescent termite nests from Central Brazil and for this reason general aspects of the bioluminescence related to the elaterid fireflies were also given. The adaptations to live in nest environment and functional categories of association of all beetle larvae we have studied, including those not bioluminescent, to termite nests are discussed in this work.

\section{Introduction}

We present here a synthesis of our papers dealing with beetle larvae found inside termite nests in Brazil, Africa (Sudan, Tanzania, Guinea, and Ivory Coast) and Australia, pointing out some aspects not dealt with yet.

A numerous and diversified insect larval fauna including many beetle species is found in the interior of termite (Isoptera) nests. This fauna occurs in living colonies as well as in abandoned nests. The inside of the nest provides stable environment protected against climatic variations and enemies. In many cases the termite nest seems to constitute the main or the only place where these beetles can develop.

For many years we collected and studied Coleoptera larvae, associated with termite nests, mainly species of the families Elateridae, Passalidae, Melyridae, Scarabaeidae, Tenebrionidae, and Carabidae. As most of the studied species were described by us in several papers and in a book in
[1], and the species reported associated with the termite nests are of different taxa, we find it worthwhile presenting a synthesis of the gathered observations, pointing out some aspects not dealt with yet. We had had the opportunity to study larvae of Elateridae (Tetralobini) from Africa and Australia [2,3] also collected from the inside of termite nests.

The phenomenon of the bioluminescent termite nest from Central Brazil is very impressive; it is the result of the luminescent activity of Pyrearinus termitilluminans Costa, 1982 (Elateridae, Agrypninae) larvae, which are found in old nests of Cornitermes cumulans (Kollar in Pohl, 1832) (Termitidae, Nasutitermitinae), one meter or more in height. These larvae excavate an intricate network of tunnels in the outer layers of the mounds leading outside, from where they stick out their head and their green shining luminous prothorax (in dorsal decubitus) to attract and catch flying preys, especially termites and ants (Hymenoptera, Formicidae). 


\section{Methods}

The methodology included the collection of larvae, pupae, and living adults for correlating immatures and adults, and identifying the species. Depending on the species, the correlation larva/adult was made on the spot and then both were properly fixed. In other cases, depending on the larval instars, it was necessary to maintain them in the laboratory for no longer than two years. When a large larval series of the same species was collected and the laboratory rearing had been successful, it was possible to preserve larva, pupa, and adult. Being the number of larvae small, we generally photographed the pupa and preserved the larva and the adult. If there was a single larva, the pupa was photographed, the larva and pupa exuviae were preserved, and the adult was obtained.

The data presented in this paper were based on Brazilian species reared from larval to adult stage, deposited in the immature beetle collection of the Museu de Zoologia da Universidade de São Paulo. Australian specimens studied by us were provided by John Francis Lawrence (CSIRO) and reared specimens from Africa by Claude Girard (MNHNP).

The species studied in our papers are the following. Brazil. Mato Grosso, Taiamã Island, in arboreal nest of Anoplotermes sp. (Termitidae, Apicotermitinae)—Veturius transversus (Dalman, 1817) (Passalidae, Passalinae), and Anchastus brunneofasciatus Schwarz, 1906 (Elateridae, Elaterinae, Dicrepidiini) [1]. Goiás. Parque Nacional das Emas, in Cornitermes sp. nest-Odontocheila auripennis Lucas, 1857 (Carabidae, Cicindelinae), P. termitilluminans (Elateridae, Agrypninae), and Lemphus sp. (Melyridae, Malachiinae) [1]. São Paulo. Itanhaém, Restinga Vegetation, in termite nest of Microcerotermes sp. (Termitidae, Termitinae)-Homophileurus luederwaldti (Ohaus, 1910) (Scarabaeidae, Dynastinae); in nests of Apicotermitinae and Nasutitermitinae-Dilobitarsus abbreviatus Candèze, 1857 (Agrypninae) [1]. Sudan. Kordopan, Khuei, from dead tree-Tetralobus cavifrons Fairmaire, 1887 (Agrypninae, Tetralobini) [2]. Tanzania. Lake Manyara National Park, in termite nest-T. subsulcatus Guérin-Méneville, 1847 [2]. Guinea. Mont Nimba, in dead termite nests of Macrotermes sp. (Termitidae, Macrotermitinae)-T. arbonnieri Girard, 2003 [3]. Ivory Coast, Savanna of Lamto near N'Douci, in termite nests-T. gigas (Fabricius, 1801) and T. shuckhardi (Hope, 1842) [3]. Australia. Victoria. Wodonga, in outer casing of Coptotermes lacteus (Froggatt, 1898) (Rhinotermitidae, Coptotermitinae) mound, in termite mound and in termite infested log-Pseudotetralobus compared with murrayi (Candèze, 1857) (Agrypninae,Tetralobini) [2] .

\section{Bioluminescence}

The emission of cold light by living beings has been the object of curiosity and scientific interest. It occurs both in plants and animals as well. Bioluminescence appears in various species of bacteria, mushrooms, seaweed, coelenterates, clams, arthropods, annelids, echinoderms, and fishes [4]. It is the product of a chemical reaction, biologically functional, catalyzed by enzymes, resulting from highly exergonic oxidations in which the energy is preferentially liberated in the form of light. The most representative bioluminescent beetle families in Brazil are Elateridae, Lampyridae, and Phengodidae (Elateroidea). They are popularly known as lightning bugs, fireflies, or glow worms.

In the Coleoptera, the luminescence can occur in adults of both sexes or is restricted to females; it can also be present in the larvae. There is much speculation on the subject of the origin and function of the luminescence in the Coleoptera, being still the cause of many unsolved questions, not deeply studied and not clearly understood.

The bioluminescence in animals can assume important functions in the intra- and interspecific communication such as sexual attraction, defense, camouflage, and attraction of the preys with feeding purposes $[5,6]$.

The bioluminescence in Coleoptera can develop the following relations.

(1) Mutual recognition between individuals. At least in the adults of the species that possess some degree of sexual dimorphism, the function of the luminescence would be to enable the recognition of the opposing sexes at a certain distance in the darkness [7]. The recognition can also occur between youths and adults of the same species.

(2) Defense, acting as warning signal to some predators. In many cases bioluminescence can only have evolved from a defensive function, since there are evidences that at least some fireflies are unpalatable to some vertebrate predators $[8,9]$. It was demonstrated experimentally that a potentially important predator learns to avoid larval glowworms by using the light signals as aposematic cues [7] and it was proved experimentally that some Lampyridae species can be unpalatable to certain vertebrates, but not to toads and bats, nor to arthropods, like some spiders that attack and eat fireflies voraciously. On the other hand, some beetles of other families mimic the colorful patterns of some Lampyridae, which suggests them have repellent properties. The defensive function can be evidenced in larvae of Phengodidae, which increase the luminous intensity when stimulated or attacked by predators [10-13]). In Pyrophorini (Agrypninae) larvae increase of luminescence under stimulation was also observed [14]. Synchronized emission of light by several individuals, adults and larvae, would increase the signal of warning against possible predators [15].

(3) Attraction of preys. The use of bioluminescence by predators to attract preys is reported in a few animals. Some benthonic fish [5] possess a luminous organ in the dorsal fin which works as bait to attract them. Adult females of lampyrids of the genus Photuris LeConte, 1851 (Lampyridae, Photurinae) imitate the flashes of light of females of other species then attract males to be eaten [16]. This behavior is considered to be aggressive mimicry. Larvae of some dipteran species of the family Mycetophilidae that live in caves use the bioluminescence as lure to attract their prey [16]. Larvae of P. termitilluminans exhibit the behavior of entrapping them $[17,18])$. Each larva lives inside a U-shaped gallery that opens on to the outside, where it shows its head and its green-shining prothorax to attract and catch winged preys [19]. 


\section{Bioluminescence in Elateridae}

The adults of these fireflies are easily identified as they have a pair of luminescent oval vesicles (yellowish when the light is extinct or the insect is dead) located at the base of the posterior angles of the prothorax that emit continuous light in the green region of the spectrum. There is a third luminescent organ located in the abdominal segment I, hidden by metaventrite and that is only activated during the flight [20], so producing light generally displaced to orange-yellow [6] or to red [21]. The luminescence in adult elaterids appears to be associated with sexual attraction, yet very little has been studied about their communication system.

In the larvae the luminescence is found mainly on the pronotum, and in some species, there are paired, lateral round organs or transverse dorsoventral zones on each abdominal segment [14]. Elateridae larvae only light up in the green area of spectrum. In the larval phase, bioluminescence may be related also with defense, but no detailed studies have been developed yet. Prepupae and pupae generally show luminescence over the entire body, with variations of intensity depending on the species. After 10-14 days of the pupal phase, it is easy to notice the outlines of the adult luminous organs. A newly emerged adult displays luminescence over the entire body, like in the pupa, but as the integument becomes darker, only the prothorax and abdominal organs emit light $[14,22]$.

\section{The Bioluminescent Termite Nest from Central Brazil}

5.1. Historical Review. In the natural world indescribable spectacles of beauty due to emission of light produced by living beings are known. Doubtlessly, in America, one of the most astonishing is the one offered by the "bioluminescent termite nest" that can be watched in the Open Cerrados of Central Brazil. Among the chroniclers, travelers, and naturalists who have written on the bioluminescent termite nests from Brazil, we can distinguish the report by Laporte [23] in Água Limpa (MT, Brazil). Laporte's comments were very accurate and he correctly identified the causes of the phenomenon "small phosphorescent larvae" that from the inside of the galleries of the termite nest produced tiny pinpoints of light. He described: Aux environs de la ferme d'Agoa-Limpa (sic), nous observâmes, durant la nuit du 15, une masse lumineuse située au milieu du Campo, et qui excita vivement notre curiosité. En approchant, nous reconnûmes que c'etait une butte de termites, d'où sortaient une multitude de petits foyers lumineux. Ce phénomène est produit par la présence d'une infinité de petites larves phosphorescentes qui se retiraient dans les galeries qu'elles s'étaient ménagées dès qu'on tentait de les saisir.

This phenomenon was also noticed in the Amazon region. It was reported that in the neighborhoods of Santarém, Pará, there were luminous termite nests whose light came from insects: The Termites, on the contrary, live in large, irregular, conical mounds, hard as rock, and often ten feet and more high. In the daytime there is no sign of life, but if one enters the forest at night the sight is a beautiful and startling one - the darkness is intense. Here and there in the blackness may be seen clusters of glittering phosphorescent light; these are the Termite hills. No doubt, the light proceeds from the insects as the particles of the light mass move and change. The light is greenish and soft, and the effect is indescribable [24, 25].

Some explanations about the phenomenon of the luminous termite nests were given by other travelers. They realized that the light was originated from phosphorescent mushrooms, bacteria, or even from luminous insects [2628]; also that the luminosity came from some insects, such as larvae of fireflies or dipterous that would live in the termite nests [29]. It is worth mentioning [27]: I have just received authentic information to the effect that in the State of Matto Grosso (sic), in the low, swampy lands along streams, and especially in the rainy months beginning with October, myriads of fireflies are seen covering the ground. My informant, who has lately come from the upper part of Matto Grosso where it joins Bolivia, tells me that he has seen at night many of the nests of white ants that have been abandoned by the ants themselves entirely covered by fireflies that come from the small openings over the whole surface of the ant-hill. Is it possible that the fireflies select these abandoned ant-hills as places in which to grow their larvae?... Unfortunately I have never observed anything of the kind here about, though I have been interested in the subject in order to furnish you information. Schaller $[30,31]$ observed luminous termite nest in Manaus (Ducke/INPA Reserve): we found an abandoned termite nest which appeared illuminated like a Christmas tree. It soon became clear that hundreds of Hemirhipus sp (=Pyrearinus fragilis Costa, 1978) [20] larvae were living in superficial holes lying in wait for crawling or flying small animals.

Kent Redford, when studying anteaters in the Parque Nacional das Emas, Goiás, Brazil, was very impressed with the phenomenon of the bioluminescent termite nests. In November 1981 in a letter to Costa, he wrote: the landscape at the Park is covered with Cornitermes mounds in which live larvae which I believe are of the genus Pyrophorus. During the beginning of the rainy season, these larvae partially emerge from holes in the termite mounds, and, from the segment immediately behind the "head", emit a bright light. It is possible to find several hundreds of these larvae in one mound and the view at night is breathtaking. Costa studied the specimens sent by Redford and concluded that they were a new species, [17] Pyrearinus termitilluminans, which means "green fire that illuminates the termite nest". Thanks are due to to the works carried through by Redford, the origin of the light in the luminescent termite nests was finally elucidated and Laporte's hypothesis [23] was confirmed. In the region of the Parque Nacional das Emas, there is great concentration of C. cumulans nests (Figure 1), being its mean density 55 nests/hectare. There are also some termite inquilines of the genus Paracornitermes Emerson, 1949 (Nasutitermitinae), morphologically similar to Cornitermes Wasmann, 1897, that were surely mistaken by Redford for Cornitermes. The dynamics of settling of the great termite nests is related to the aging of the nests of C. cumulans (L. R. Fontes, personal communication) [21]. 


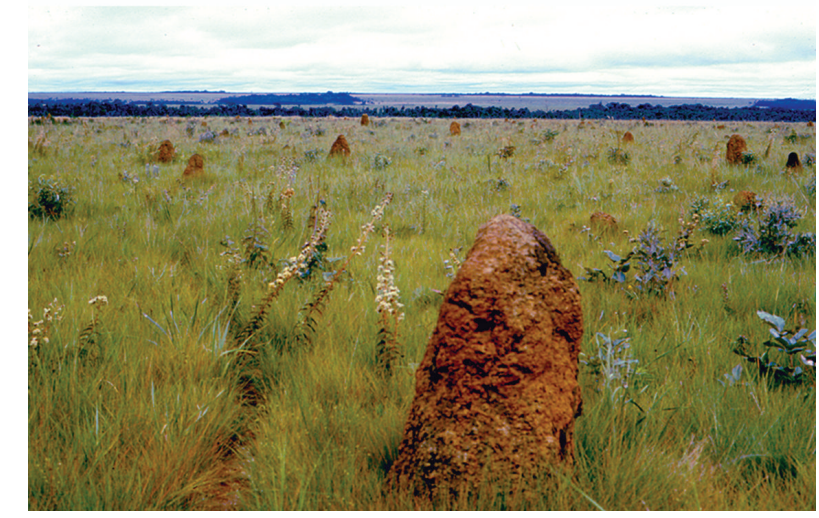

Figure 1: Parque Nacional das Emas, Goiás, Brazil, field with numerous termite nests, general view (photo: S. A. Vanin).

In August 1982, Erwin reported to Costa (pers. comm.) on his findings about another type of luminescent termite nest inside the forest in Puerto Maldonado (Rio Tambopata), Madre de Dios, Peru. He collected larvae and adults at the base of a dead tree, partially covered with soil. These larvae remained inside of orifices of the wood and shone at night, producing some points of greenish light on the trunk where they had been found. Erwin wrote: In young terre (sic) firme Forest at the base of dead trees were uplifts of soil around the base. At night while walking near these trees I noted many little points of blue light. Upon investigating I found many small burrows like tiger beetle burrows. To my surprise I got a larva or adult elaterid from the holes. These specimens were identified as $P$. fragilis and the larva was described in 1986 [14]. Although apparently less spectacular, the phenomena observed by Erwin in Peru and Schaller in Manaus are quite similar to that of the Parque Nacional das Emas.

\subsection{The Elaterid Genus PYREARINUS Costa, 1975. This} genus congregates 43 South American species, in seven species groups; 35 species being found in Brazil. Pyrearinus termitilluminans, a species of the pumilus group, is very abundant in the Parque Nacional das Emas. Invariably, larvae, pupae, and adults of that species were found in older nests of C. cumulans, about $1 \mathrm{~m}$ high or more, and invaded by other species of termites, mainly of the genera Paracornitermes, Spinitermes Wasmann, 1897 (Termitinae), and Embiratermes Fontes, 1985 (Nasutermitinae). In three broken up nests 142 larvae of $P$. termitilluminans were found on average. This is the first species of elaterid whose larvae were found in a network of galleries in termite nests opening on to the outside. In Brazil, the phenomenon of the luminescent termite nests (Figure 2) can be observed mainly from April to October. On the warm and humid nights of spring and summer, hundreds of larvae in each termite nest, soon after twilight, are positioned to exhibit its luminescent pronotum [19], and the termite fields look like miniature cities or countless illuminated Christmas trees. The female of $P$. termitilluminans lays its eggs at the base of the termite nests. After hatching, the larvae dig small galleries in the

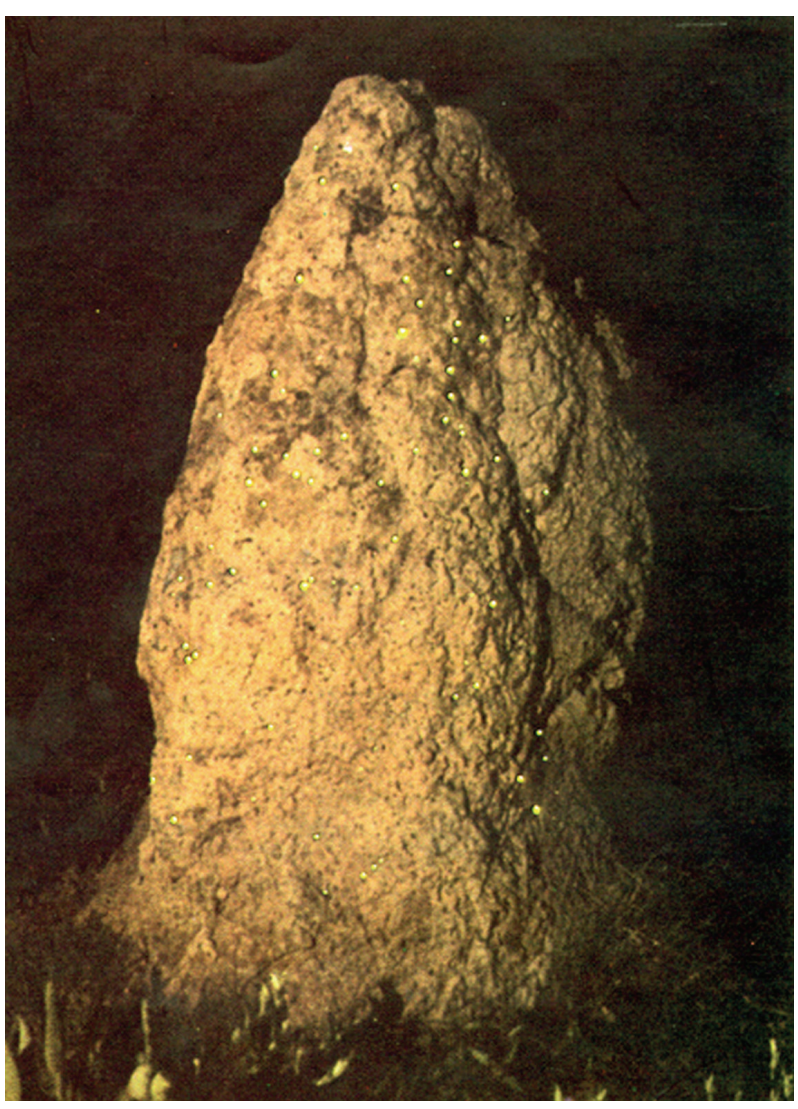

Figure 2: Parque Nacional das Emas, Goiás, Brazil, luminous termite nest (photo: S. A. Vanin).

walls where they live. The nests provide a vertical surface or "tower," causing the light produced by the larvae to be more visible and then making the prey attraction easier. The hunting position of the larva in the galleries seems to be very strategic. At night, the ventral part of its body is upturned in relation to the ground nest and the larva exposes its bending head and prothorax out of the gallery in such a way as to exhibit the luminescent pronotum to attract preys (Figure 3), generally butterflies, winged termites, and ants. Pupae and adults were also found inside sealed galleries with their shed larval skins. Adults (Figure 4) can also be collected flying at night in the neighborhood of the termite nests [17].

In internal chambers of one of the termite nests examined in the Parque Nacional das Emas, we found fragments of adults of $P$. termitilluminans (female) and scarab beetles. It is possible that some females enter the termite nest to lay their eggs and die there. Another probable oviposition place of $P$. termitilluminans is the base of the termite nest zone, where the first instars are always found brightly illuminating the area.

5.3. The Pumilus Group. The pumilus group includes, apart from $P$. termitilluminans, five more species: P. flatus Costa, 1975-Brazil (SP, MT) and Paraguay; P. fragilis-Brazil (PA, RS); P. pumilus (Candèze, 1863)_Brazil (GO, MG, SP); P. scintillula (Candèze, 1881)_Guyana, Ecuador, Brazil 


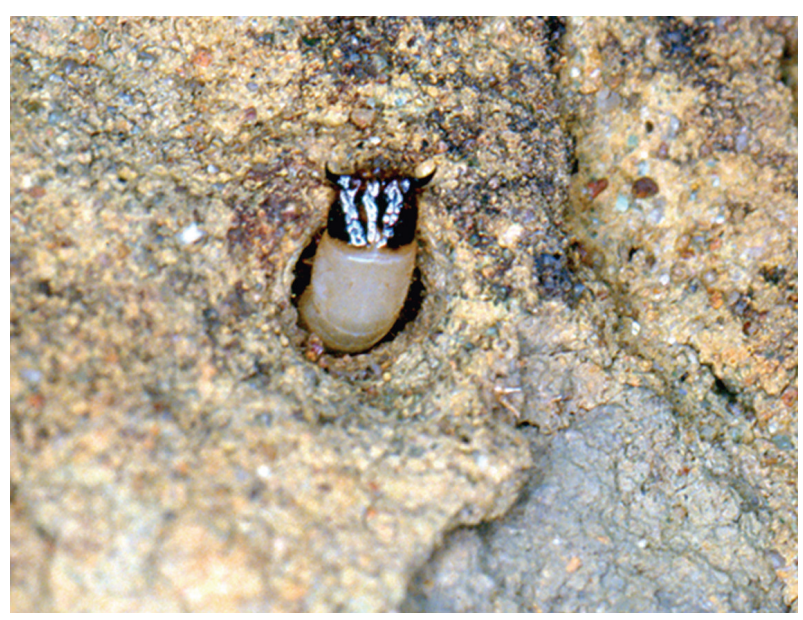

Figure 3: Pyrearinus termitilluminans Costa, 1982 (Elateridae, Agrypninae), larva, head and prothorax, dorsal decubitus, in the outer opening of the gallery. Parque Nacional das Emas, Goiás, Brazil (photo: S. A. Vanin).

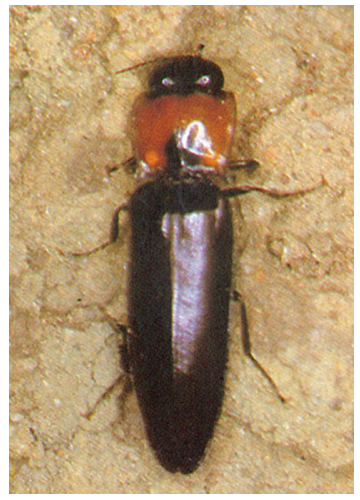

(a)

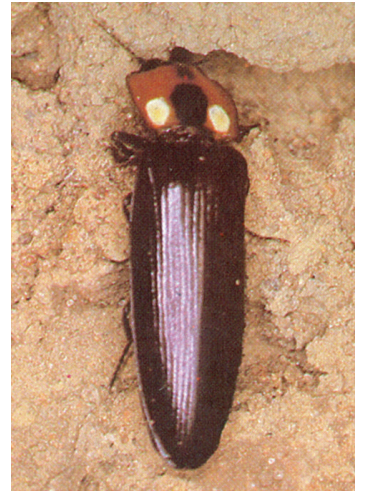

(b)
Figure 4: Pyrearinus termitilluminans Costa, 1982 (Elateridae, Agrypninae), male and female (note the large and salient eyes of male). Parque Nacional das Emas, Goiás, Brazil (photo: S. A. Vanin).

(AM, PA)—Peru, Bolivia; and P. vitticollis (Germar, 1841)Brazil (ES) [20, 32]. The geographic distribution of that group [20] shows some species in the Brazilian open formations and others in the Amazonia forested region.

On the map (Figure 5), showing the localities where luminous termite nests were reported by earlier naturalist and travelers, there is certain overlapping between their distribution and that species of the pumilus group. For example, de Caumat de Laporte Castelnau [23] observed the phenomenon of luminous termite nests in "Água Limpa," Mato Grosso; Smith [26] verified the occurrence of the phenomenon in a place close to Santarém (Tapajós Valley), Pará; Knab [24] reported the presence of luminous termites in Low Amazon; Knab [25] in Santarém, Pará; Branner, [33, 34], cited information on luminous termite nests received from Lustosa, in Mato Grosso, next to Bolivia; Neiva and Penna [28] mentioned the occurrence of the phenomenon in Goiás without specific locality and in the "Gerais Baianos",

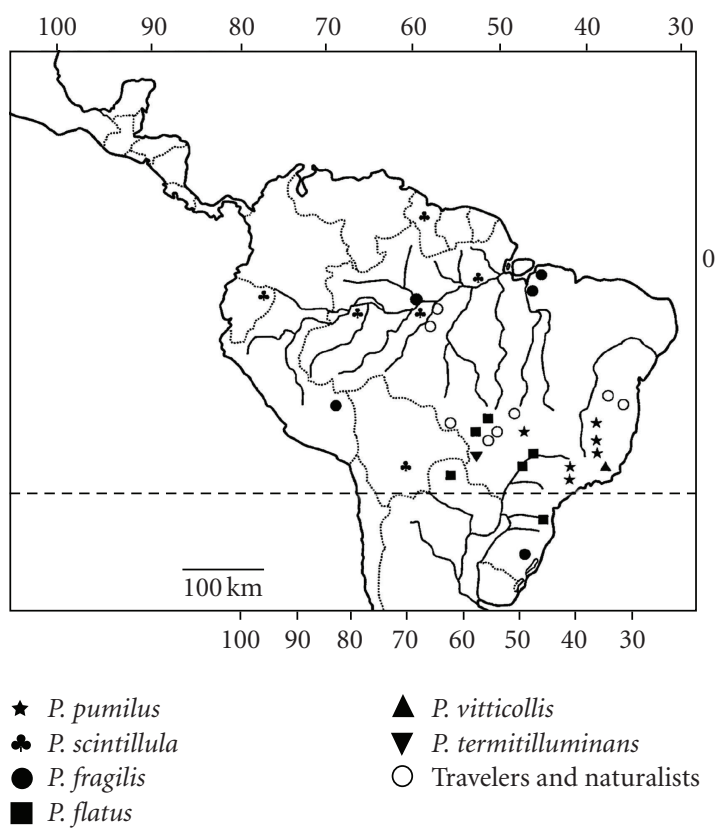

Figure 5: Map with distribution of Pyrearinus, group pumilus (Elateridae, Agrypninae) species, and records of occurrence of luminescent termite nests by naturalists and travelers.

Lage, São G. B. Raimundo Nonato municipality and in Jatobá Remanso municipality; Fonseca [35]) and da Fonseca and de Almeida [36] registered the occurrence of luminous termite nests in Rio Verde, Mato Grosso; Lenko and Papavero [37] and Marien [38], on the Raizama river, and Otero [39]) in Goiás. Costa [17] considered the distribution of species of the pumilus group associated with the termite nests' distribution.

Pyrearinus termitilluminans is very similar to $P$. fragilis. Larvae of the latter were collected inside luminous ground wooded termite nests from Peru [17], and Manaus, Amazonas, Brazil [30]. Specimens of P. fragilis from Rio Grande do Sul, Brazil were recorded to live inside termite nests, but there are no references if they were luminescent or not [20]. Larvae of $P$. termitilluminans (Figure 6) and of $P$. fragilis from Manaus were reared up to adults, while the larvae of $P$. fragilis from Peru were collected associated with the adults $[17,30]$. The larval behavior of $P$. fragilis from Peru and Manaus is quite similar to those of $P$. termitilluminans; they remain inside of orifices of the wood infested by termites or small ground termite nest, with the anterior region emitting light and attracting preys $[14,30]$. However, larvae of both species are quite different from the other known larvae of the same genus. They have bodies less dorsoventrally flattened, less sclerotized, and feebly pigmented; the abdominal segment IX is rounded, without tubercles; the anal hooks are less developed and the stemmata are dark pigmented. These characters seem to be adaptations to the life inside the galleries $[14,17]$.

The larvae of $P$. termitilluminans illuminate intensely the prothorax and the abdominal segment IX. The larval galleries form an intricate superficial mesh (Figure 7) of 


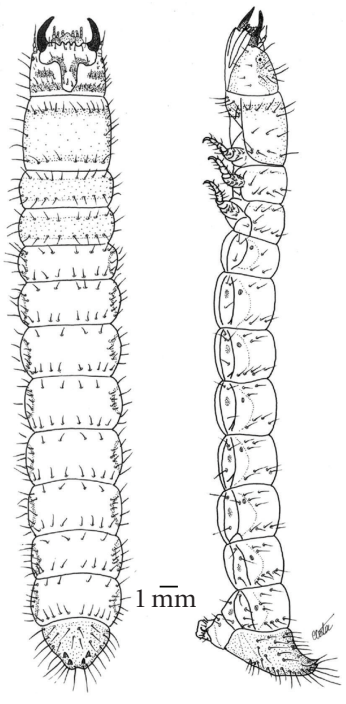

Figure 6: Pyrearinus termitilluminans Costa, 1982 (Elateridae, Agrypninae), larval drawings (dorsal, lateral). Parque Nacional das Emas, Goiás, Brazil (after Costa, 1982).

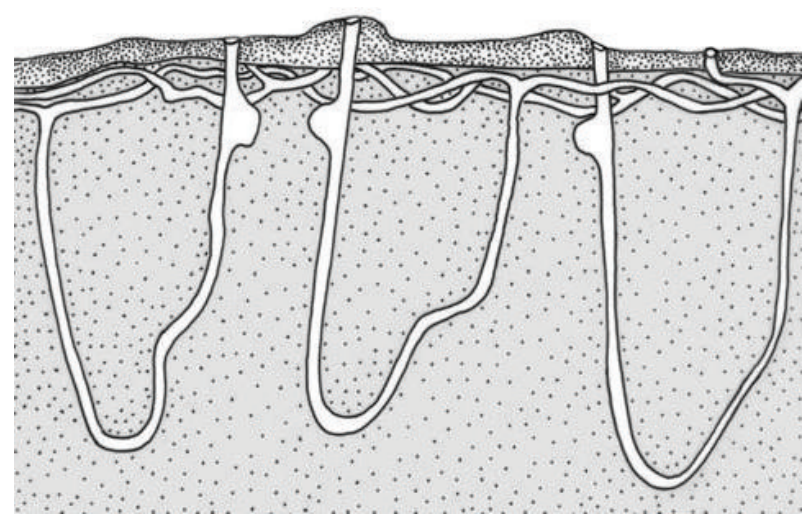

FIgURE 7: Pyrearinus termitilluminans Costa, 1982 (Elateridae, Agrypninae), scheme of galleries constructed by the larvae in the surface Cornitermes cumulans (Kollar in Pohl, 1932) (Termitidae, Nasutitermitinae) nests. Parque Nacional das Emas, Goiás, Brazil (after Bechara, 1988, modified).

tunnels with 0.1 to $0.3 \mathrm{~cm}$ in diameter, occupying almost the whole surface of the nest [21]. Each individual " $U$ "shaped gallery opens on to the outside; the arm of the U near the exit hole has a small atrium that seems to constitute a place for stockpiling predigested prey and also for facilitating the inversion of displacement of the larva in the gallery, as if it were a "marshaling yard". It is possible that the lantern of the abdominal segment IX serves to signal the presence of the larva in the tunnel, for there are many larvae in each nest (one each $10 \mathrm{~cm}^{2}$ ), and thus to prevent the cannibalism, which is noticed in the laboratory when some larvae are kept together. The in vivo larvae bioluminescence increases sharply with the elevation of the temperature and this mechanism should be related to the hunting behavior [40].
Larvae of four different species of other Pyrearinus groups are known as $P$. candelarius Germar, 1841, P. candens (Germar, 1841), P. janus (Herbst, 1806), and P. micatus Costa, 1978. They differ from those of the pumilus group in the depressed, quite sclerotized and pigmented body, abdominal segment IX depressed and with many tubercles. Larvae of $P$. candelarius were collected in dead trunks and inside ground termite nests. The larvae of $P$. candens showed no luminescence, yet those of $P$. candelarius emitted light when stimulated, first in the prothorax and then in the lateral and dorsal regions of almost all abdominal segments. The larvae of $P$. janus and $P$. micatus illuminated intensely the prothorax, and almost all abdominal segments, in lateral and dorsal points [14, 32].

\section{Other Larvae of Beetles Related to the Termite Nests}

More than 1,500 species of termitophilous insects are known today [41]. The Brazilian Coleoptera families that have been studied and include species living associated with termite nests are Elateridae, Passalidae, Melyridae, Scarabaeidae, Tenebrionidae, and Carabidae. Considering the species of these families, the termite nest seems to be the ideal place for their whole development or important for part of their life cycles. In general, these beetles are so well adapted that, if removed from the termite nest, they do not resist and die in a short period of time [42]. The larvae have a greater dependence on the termite nest environment than adults, because larvae depend on the available food resources found inside the nests or upon preys that are attracted from the outside by light emission. These larvae can be saprophagous, mycetophagous, or predators, attacking the termites in the living colonies or other insect hosts, especially in dead colonies.

Some of these species present a curious structural modification in the abdomen, called physogastry. The abdomen is gradually enlarged or swollen, generally by possible growth of the interconnective membranes, expansion of the adipose body, and secondary sclerotization of the abdominal sternites. As a result, it resembles the abdomen of a termite queen. The physogastric abdomen was developed independently in some lineages of Coleoptera: in adults the species of the coroticines (Staphylinidae, Aleocharinae, Coroticini) and the Scarabaeidae presented it, in larvae the Carabidae and Elateridae did.

Physogastric larvae of the elaterid $D$. abbreviatus were collected inside epigeous nests of soil-feeding termite genera Anoplotermes Fr. Müller, 1837, Araujotermes Fontes, 1982, Atlantitermes Fontes, 1979, and Subulitermes Holmgren, 1910 (Nasutitermitinae), Atlantitermes Fontes, 1979 (Nasutitermitinae), and Subulitermes Holmgren, 1910 (Nasutitermitinae) in the Restinga Vegetation (6-12 $\mathrm{m}$ in height) in Itanhaém, a seaside town of the state of São Paulo [43].

Physogastric larvae of Pseudotetralobus spp. (Australia: Victoria, New South Wales, Queensland, and Northern Territory) were collected in varied environments: "in termite infested logs", "in chambers next to termite galleries", "in rotten logs", and "in outer casing of Coptotermes lacteus 


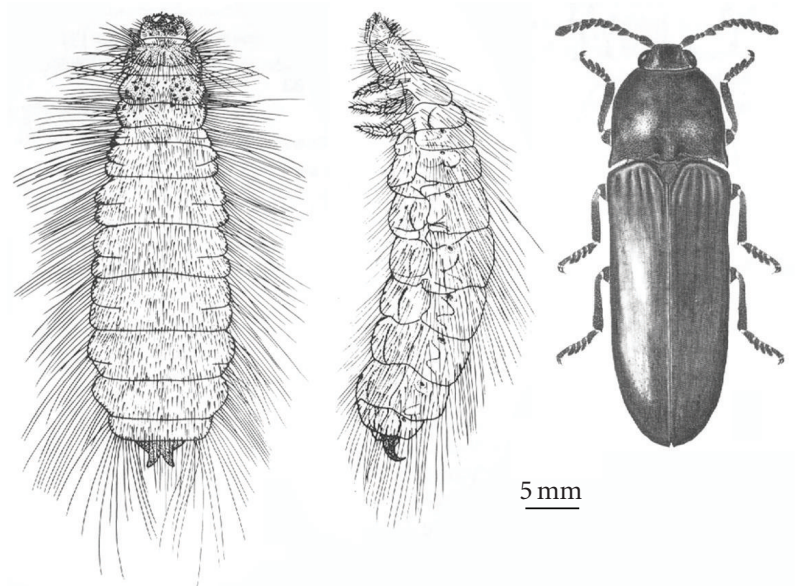

Figure 8: Tetralobus cavifrons Fairmaire, 1887 (Agrypninae, Tetralobini), larva (dorsal and lateral) and adult (dorsal), inside termite nest. Kordopan, Sudan (after Costa et al., 1992).

mounds". The larva of T. cavifrons from Africa, Sudan (Figure 8), collected from the wood of a dead tree of Acacia sp. (Fabaceae), is also physogastric. These larvae resemble termite queens, but they have the body densely covered with a diverse kind of setae, and their heads are almost phragmotic (in resting position are obliquitous to body axis) [2]. They run actively over the ground, crawling very quickly and extending and contracting their body as they progress $[44,45]$. Larvae of T. arbonnieri, T. gigas, and T. shuckhardi are widely distributed in Ivory Coast and Guinea and were collected inside galleries of the shield of dead nests of Macrotermes Holmgren, 1910, are also physogastric, and have phragmotic heads, which suggest that they are probably predators of termites and other small insects. Apparently, the galleries do not open in the nest outside. Their occurrence in termite nests seems regular. These nests represent a very ad hoc environment to complete their postembryonic development [3].

The development of glands in the abdomen or in other regions of the body is frequent, too. The glands secrete substances that surely influence the relations between the termitophilous beetles and the termite hosts. The larvae of T. subsulcatus, T. arbonnieri, and T. shuckhardi have glands in the dorsal area of abdominal segment VIII, but their function remains unknown $[2,3]$.

Immatures of A. brunneofasciatus (Figure 9), which inhabit epigeous termite nests in marshy areas, $10 \mathrm{~km} \mathrm{~S}$. of the island of Taiamã, the right bank of the Paraguay river, Mato Grosso, Brazil [43], of the passalid V. transversus (Figure 10) collected inside the same nest [46], and immatures of Lemphus sp. (Cleroidea, Melyridae) (Figure 11), collected inside termite nest in the Parque Nacional das Emas, are not physogastric. The larvae of Lemphus sp. are very conspicuous by having salmon color and a short velvety yellowish pilosity [1].

A detailed study on infestation of arborous carton nests of Microcerotermes sp. by the H. luederwaldti (Phileurini) [47] (Figure 12) demonstrated that the larvae of the
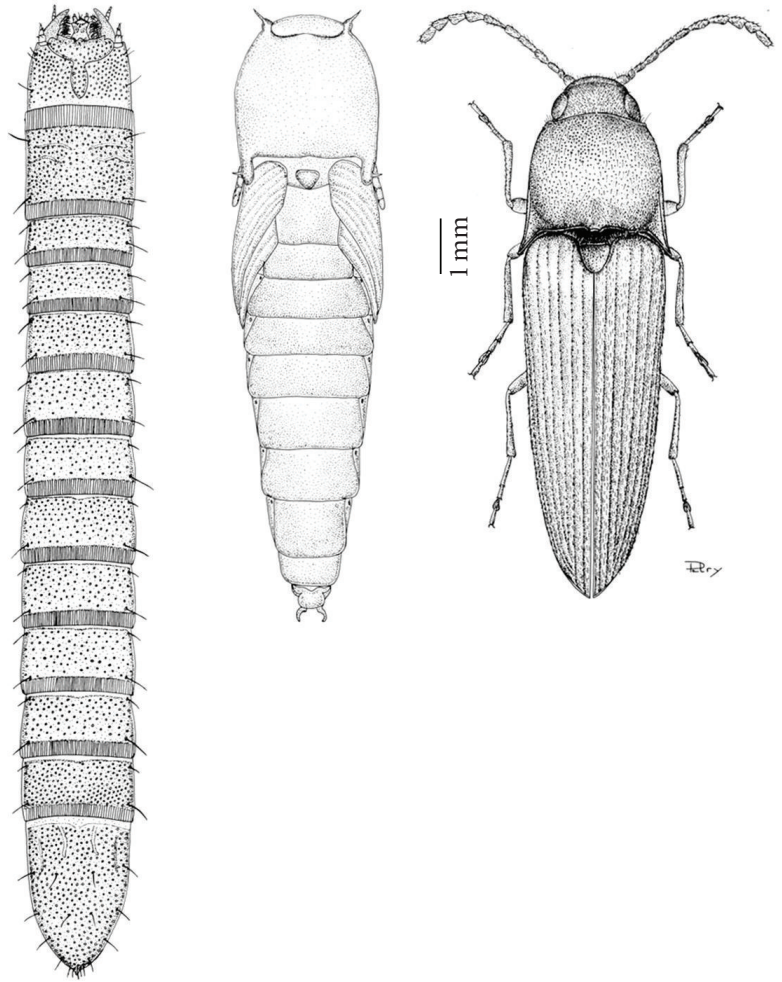

FIGURe 9: Anchastus brunneofasciatus Schwarz, 1906 (Elaterinae, Dicrepidiini) larva, pupa and adult (dorsal), inside Cornitermes cumulans (Kollar in Pohl, 1832) (Termitidae, Nasutitermitinae) nest., Parque Nacional das Emas, Goiás, Brazil (after Costa et al., 1988).
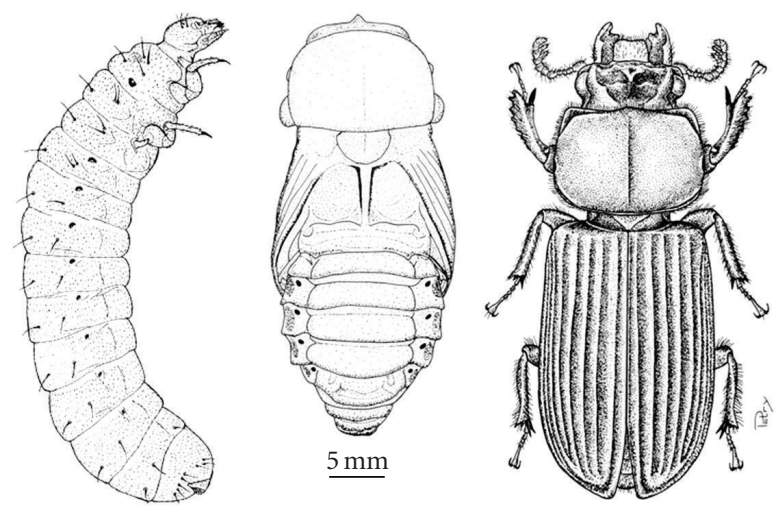

Figure 10: Veturius transversus (Dalman, 1817) (Passalidae, Passalinae), larva (lateral), pupa and adult (dorsal), inside Cornitermes cumulans (Kollar in Pohl, 1832) (Termitidae, Nasutitermitinae) nest. Parque Nacional das Emas, Goiás, Brazil (after Costa et al., 1988).

Scarabaeidae feed on the walls of the nest itself. The wall is constituted of remaining portions of chewed wood and termite excrements and provides necessary energy for the development of the larvae. Having completed the feeding phase, the larvae construct pupal chambers in the inner walls of the nest. After the metamorphosis, the adults leave 

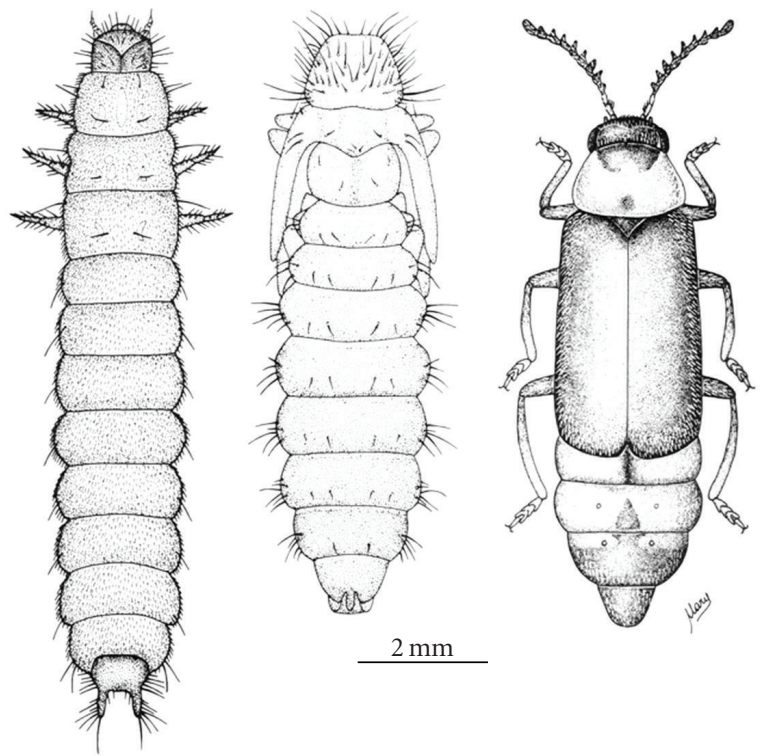

Figure 11: Lemphus sp. (Melyridae, Malachiinae), larva, pupa and adult (dorsal), inside Cornitermes cumulans (Kollar in Pohl, 1832) (Termitidae, Nasutitermitinae) nest. Parque Nacional das Emas, Goiás, Brazil (after Costa et al.,1988).
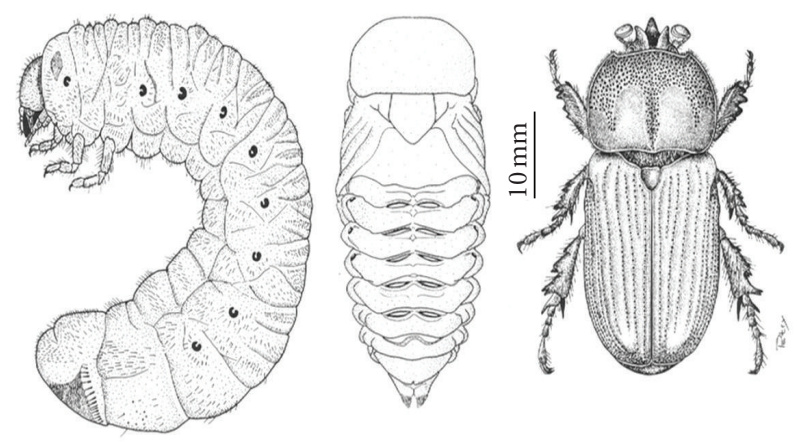

Figure 12: Homophileurus luederwaldti (Ohaus, 1910) (Scarabaeidae, Dynastinae), larva (lateral), pupa and adult (dorsal), inside Microcerotermes sp. (Termitidae, Termitinae) nest. Itanhaém, São Paulo, Brazil (after Vanin et al., 1983).

the nest by excavating a canal to the exterior (Figure 13). The activities of the larvae and adults of the Scarabaeidae can cause great damages to the termite nest, resulting sometimes in its destruction. It must be stressed that the termites do not attack living larvae, pupae, or adults and are not able to defend the nest against beetle's attacks, yet they occasionally enclose the beetles that die inside the colony with newly built nest material. It is interesting to notice that the fecal pellets produced by the larvae serve as food for hundreds of larvae of alleculine beetles (Tenebrionidae, Alleculinae) (Figure 14). Larvae of $H$. luederwaldti and of another Phileurini species, Actinobolus trilobus Luederwaldt, 1910, were observed inhabiting arborous nests of two species of Nasutitermes Dudley, 1890, suggesting an association between the Phileurini and the Nasutitermitinae [48].

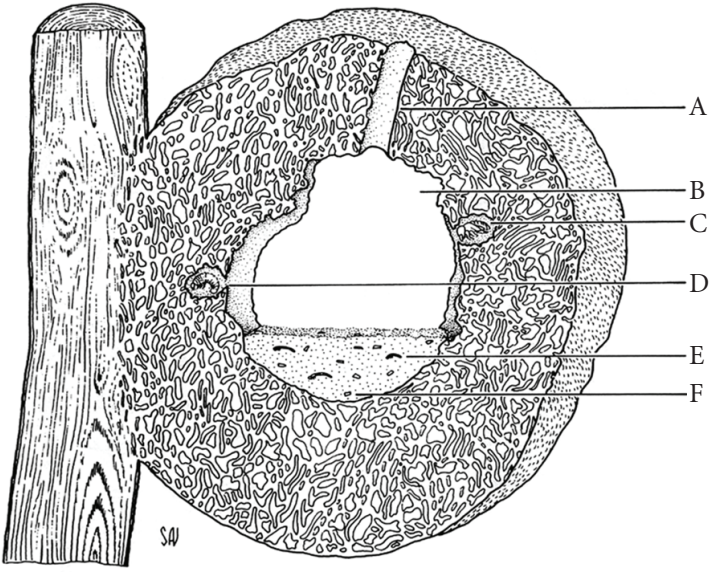

Figure 13: Microcerotermes sp. (Termitidae, Termitinae), transversal section of the nest: (a) the canal; (b) central chamber; (c) pupal chamber of Homophileurus luederwaldti (Ohaus, 1910) (Scarabaeidae, Dynastinae); (d) larva of H. luederwaldti feeding on nest walls; (e) Lobopoda sp. (Tenebrionidae, Alleculinae) larva; (f) fecal pellets of $H$. luederwaldti larvae. Itanhaém, São Paulo, Brazil (after Vanin et al., 1983).
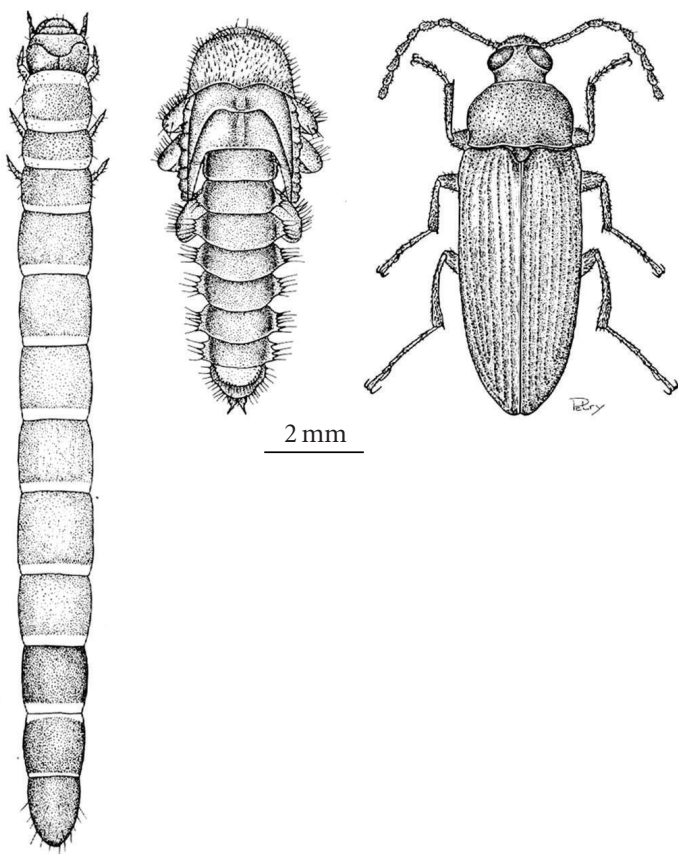

Figure 14: Lobopoda sp. (Tenebrionidae, Alleculinae), larva, pupa and adult (dorsal), inside nest of Microcerotermes sp. (Termitidae, Termitinae). Itanhaém, São Paulo, Brazil (after Vanin et al., 1983 and Costa et al.,1988).

Beetles of Cicindelinae (Carabidae) (Figure 15) and Tenebrionidae have been found associated with the luminescent termite nests of Central Brazil. The larva of $O$. auripennis is predator and lives in superficial galleries in the nests of C. cumulans. As other larvae of Cicindelinae, it possesses phragmotic head, which together with sclerotized pronotal plate, occludes the circular opening of the gallery. 


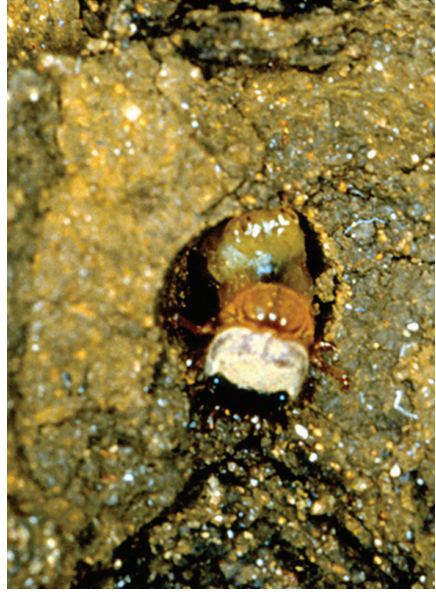

(a)

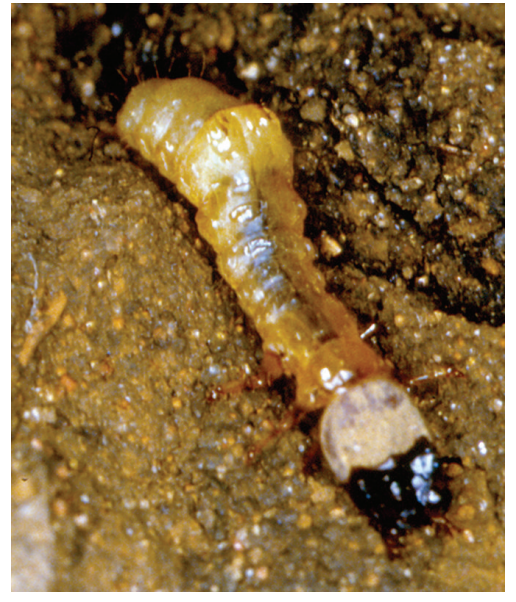

(b)

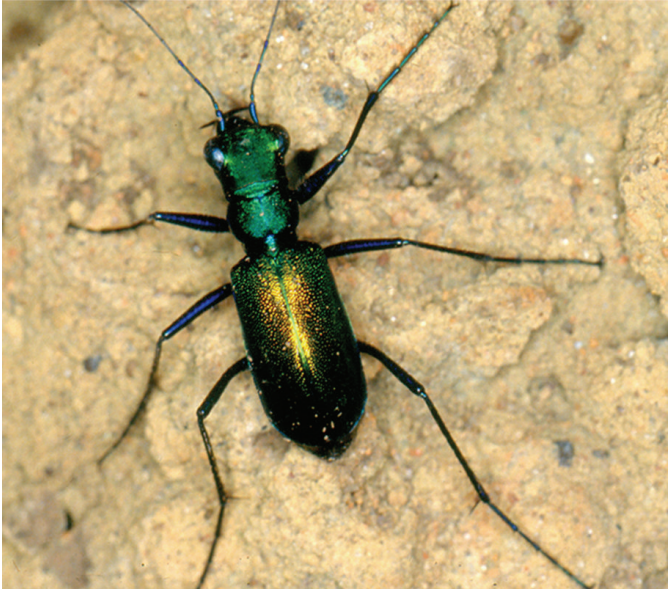

(c)

Figure 15: Odontocheila auripennis Lucas, 1857 (Carabidae, Cicindelinae) in the Cornitermes cumulans (Kollar in Pohl, 1832) (Termitidae, Nasutitermitinae) nest: larva, head, and prothorax in the external opening of the gallery; larva removed from the gallery (note the salient abdominal hooks; and adult in the external nest surface). Parque Nacional das Emas, Goiás, Brazil (photo: S. A. Vanin).

The preys are captured when they walk around the opening and are drawn to the interior of the gallery, where they are eaten. The larva has hooks in the dorsum of abdominal segment $\mathrm{V}$ that allow it to anchor firmly in the gallery wall, in the eventuality of confrontation with a larger prey that could drag it out of the gallery. It is interesting to notice that coinhabiting termite nests, where larvae of $P$. termitilluminans also occur, can be advantageous for the Cicindelinae, because both species can profit from the preys attracted by the luminescent larvae [1]. However, the adults are predators that stalk their preys in daylight. The larvae of Tenebrionidae probably dig galleries and can feed on existing organic substance in the walls of the nest itself or of any other organic substance found in its interior.

In the high termite nests of the genus Macrotermes (=Bellicositermes Emerson, 1925), called "cathedral termite nests" and abundant in African savannahs, many beetles are found mainly in those dead colonies. The African nests can exceed $3 \mathrm{~m}$ high by 2 to $3 \mathrm{~m}$ in diameter at the base [41]. The central structure of the nest (pan) is oval, about $1.3 \mathrm{~m}$ in diameter and $2 \mathrm{~m}$ high, and can contain from 30 to 50 kilos of organic substance, substratum for the culture of mushrooms. Four or five weeks after the colony's death, while the pan still contains great amount of organic substance and mushrooms, hundreds of adults and immatures of insects, mainly dermapterans (Dermaptera), heteropterans (Hemiptera, Heteroptera), and coleopterans (especially tenebrionids) (Tenebrionidae) are pullulating there and feeding on this material [41]. A large number of other insects, belonging to diverse orders and families, exploit this trophic level and constitute excellent prey for carabids (Carabidae), the main predators found there. Girard and Lamotte [41] demonstrated that the colonization of the dead termite nests of Africans Bellicositermes is initially carried through by the mycetophagous and saprophagous species, followed by the predators. This fauna is frequently very diverse and special.
The community momentarily joined together is very abundant during the first weeks, and besides it is much diversified, including several tens of Coleoptera species (Carabidae, Elateridae, Staphylinidae-Pselaphinae, and others; Scarabaeidae, Scaphidiinae, Tenebrionidae), Dermaptera, Hemiptera, and also some Lepidoptera. All these species are considered rare. The dead termite nest also serves as a shelter, mainly in the dry season. The elaterid larvae of other subfamilies were found inside the termite nest prey on termites, but are not luminescent and only occur in abandoned nests.

Experimental observations on the behavior and life history of Megaxenus spp., (Aderidae) larvae from Australia, Papua New Guinea and the Philippines found in nests of Microcerotermes spp. revealed that these larvae are adapted not only to the nest environment, but also to the social system of the termites. These larvae have mastered the trophallactic code which results in their feeding by the termites [49]. Larva of Odontonychini (Elaterinae) from Zambia collected inside termite nest probably has similar behavior (Girard and Costa, in preparation).

\section{Discussion and Conclusions}

Kistner [50,51] gave important information on inquilines of social insect nests. As many of these inquilines are obligatory predators, feeding on individuals of the colony, he preferred to call them symbionts. In the case of termites, these symbionts are called termitophilous. To him, termitophilia implies a compulsory or, at least, a long-term association. Larvae and adults of termitophilous species are accepted in the colonies, they are adapted "to decipher" and "to mimic" the "code" of the social insects. This code can be a volatile chemical substance, tactic exudates, or, still, stimulations. These substances or stimulations are, in general, responsible for the communication and the integration between the young and the adult termites of the colony. In some cases, 
the symbiotic associations are complex enough to contain taxa of many species, which result in historical processes of coevolution, as in the case of the Coroticini symbiont of the Nasutitermitinae termites. The relations between these beetles and their hosts have not been adequately investigated yet. Some species are essentially commensals. Some can feed on regurgitated food of termites, as in the case of the physogastric staphylinids of the genus Corotoca Schiødte, 1853 (Coroticini). Others, still, can be predators, feeding on their hosts [6]. Kistner [52] quotes Wasmann's report of Neoglyptus punctulatus (Chaudoir, 1862) as one of the few known obligatory associations between termite and carabid beetles. In this species, the first instar larva is campodeiform but changes after entering the nest to a scarabaeiform physogastric larva. The adults may or may not develop physogastry by hypertrophy of the fat body.

According to Araújo [53], the term termitariophilia was coined by Berg [54] to designate no obligatory predators, associations of animals with termite nests rather than with the termites, as occurs in the cicindelid Odontocheila auripennis, reported above.

The species of the Coleoptera reported herein associated with the termite nests are very diverse in the number of different taxa involved. It is quite difficult to precise the character of all the interactions noticed between the inquilines and their hosts. Therefore, the classification is very complex as it involves all ecological relations between them. However, we can place them in some functional categories.

In general, all the species studied seem to use the nest as a place to rear their larvae and pupation can occur in galleries near the outer nest surfaces. The adult has its own life out of the nest where copulation occurs; the females can lay their eggs near the nest in the soil, inside the central area of the nest, or in the nest galleries. The larvae can be found inside the central part of the termite nest or in a superficial network of galleries with or without outside exits. The larvae can be physogastric or not; predators of preys ambushed or attracted from outside; feeding on diverse organic matter, mushrooms, and excrements that are found inside the nest, or the trophallaxis feeding behavior may be present.

(1) According to the dependence of the beetle species on the termite colonies.

(1.1) Species adapted not only to the nest environment, since larvae and adults can also live inside dead logs or other similar habitats (e.g. Veturius transversus, Anchastus spp., and Lobopoda sp.).

(1.2) Species that use the nest as a place for larval development. All phases of their life cycle but adulthood can occur inside the nest (e.g. Homophileurus luederwaldti). In some particular cases, larvae are adapted to live in galleries placed in the outer walls, from where they can attract ( $P$. termitilluminans) or ambush (O. auripennis) preys from outside.

(1.3) Species totally dependent on termites and the coleopterans included in the social system of the colonies as inquilines. There is production of mimic pheromones by the coleopterans, and trophallaxis occurs between hosts and inquilines, and beetle larvae are mistaken for "termites" by the hosts (e.g. Megaxenus spp., and very likely Odontonychus spp.).

\section{(2) According to attainment of food supply.}

(2.1) Species which feed on organic matter found inside the nest, mostly in the cabbage pan, for example, tenebrionids (Lobopoda sp.), elaterids (Anchastus spp.), passalids ( $V$. transversus), and melyrids (Lemphus sp.). In some cases the species feed exclusively on the carton nest walls, as the Phileurini scarab $H$. luederwaldti.

(2.2) Species that live in galleries built inside the outer walls of the termite mound and attract or ambush preys from the outside. They can occasionally prey on termites found inside the nest (e. g. Odontocheila sp. and P. termitilluminans).

(2.3) Species which are predators of the hosts, such as elaterid larvae only found inside the nest and that prey on termites (e.g. Dilobitarsus abbreviatus, Pseudotetralobus spp., and Tetralobus spp.).

(2.4) Species that exercise trophallaxis and are fed by hosts, being regarded as true termitophiles (Megaxenus spp).

(3) According to the ecological and morphological adaptations of beetle larvae that live in termite nests.

(3.1) Larvae found inside the central part of the termite nest.

(3.1.1) Physogastric larvae, bearing some special glands and different kinds of setae forming or not tufts. In some species inclined head, almost phragmotic. Termite predators (e.g.: Dilobitarsus abbreviatus, Pseudotetralobus spp., and Tetralobus spp.).

(3.1.2) Nonphysogastric larvae, glabrous body, with very small head, anterior legs directed forwards. Larvae fed by termite workers; trophallactic feeding behavior demonstrated in Megaxenus spp. and probably in Odontonychus sp..

(3.1.3) Non-physogastric larvae, with prognathous head, found mostly in the cabbage pan. Larvae eat many kinds of organic substances found in the nest interior (e.g. Veturius transversus, Anchastus spp., Lemphus sp., and Lobopoda sp).

(3.1.4) Non-physogastric larvae, large head, feeding on the carton nest walls, which are rich in organic matter. The damage resulting from larvae feeding can cause the nest destruction (e.g Homophileurus luederwaldti).

(3.2) Larvae found in a superficial network of galleries leading outside. 
(3.2.1) Non-physogastric larvae. Predators of preys ambushed or attracted from the outside of the termite nest (e.g. O. auripennis and P. termitilluminans). To $P$. termitilluminans larvae, the nests provide a vertical surface or "lighthouse" that extends the area reached by the light emitted, thus increasing the number of flying insects that can be attracted.

(3.3) Larvae found in galleries of the shield without openings to outside.

(3.3.1) Physogastric larvae. Probably predators of termites and other small insects (e. g. Tetralobus arbonnieri, T. gigas, and T. shuckhardi) with phragmotic head and bodies densely hairy.

Very little is known about the association of beetles larvae with termite nests, although the number of works published on the subject has increased in recent years. Many hanging questions are pending about the interactions that occur between the immature and adult individuals of beetles and termites in the colony. It is also important to assemble new data about behavior, chemical, and tactile stimulations responsible for the communication between termites and their guests, and possible substances produced by glands and used as simple nutrients, stimulants, or mimic attractant pheromones of the hosts. Other relevant questions are concerned with the possible functions of morphological features, seemingly adaptative, like the phragmotic head and physogastric hairy body of Tetralobini larvae that live in galleries inside the host nest.

The authors hope that the information and commentaries presented in this paper may stimulate other researchers, especially the young people, to search for such fascinating and instigating aspect of the biodiversity.

\section{Acknowledgments}

To Sergio Ide (Instituto Biológico, São Paulo) for the critical reading of the manuscript, Carlos E. Simonka and Simone P. Rosa (Museu de Zoologia, São Paulo) for help in the electronic treatment of the figures. To Luiz R. Fontes for information on termites and termite nests. Thanks are also given to Conselho Nacional de Desenvolvimento Científico e Tecnológico (CNPq) for the Research Grant 302721/2007 - 0 to C. Costa.

\section{References}

[1] C. Costa, S. A. Vanin, and S. A. Casari-Chen, Larvas de Coleoptera do Brasil, Museu de Zoologia, Universidade de Sao Paulo, Sao Paulo, Brazil, 1988.

[2] C. Costa, S. A. Casari-Chen, and S. A. Vanin, "On the larvae of Tetralobini (Coleoptera, Elateridae)," Revista Brasileira de Entomologia, vol. 36, no. 4, pp. 879-888, 1992.

[3] C. Girard, C. Costa, and S. P. Rosa, "Présence insolite de larves et de nymphes de Tetralobus (Coleoptera : Elateridae), dans des termitières mortes de Macrotermes (Isoptera): données sur la morphologie et la bionomie de larves et de nymphes de trois espèces," Annales de la Société Entomologique de France, vol. 43, no. 1, pp. 49-56, 2007.

[4] P. J. Herring, Ed., Bioluminescence in Action, Academic Press, London, UK, 1978.

[5] J. Buck, "Functions and evolutions of bioluminescence," in Bioluminescence in Action, P. J. Herring, Ed., pp. 419-460, Academic Press, London, UK, 1978.

[6] R. A. Crowson, The Biology of Coleoptera, Academic Press, London, UK, 1981.

[7] J. E. Lloyd, "Firefly parasites and predators," The Coleopterists Bulletin, vol. 27, no. 2, pp. 91-106, 1973.

[8] R. de Cock and E. Matthysen, "Aposematism and bioluminescence: experimental evidence from glow-worm larvae (Coleoptera: Lampyridae)," Evolutionary Ecology, vol. 13, no. 7-8, pp. 619-639, 1999.

[9] R. de Cock and E. Matthysen, "Glow-worm larvae bioluminescence (Coleoptera: Lampyridae) operates as an aposematic signal upon toads (Bufo bufo)," Behavioral Ecology, vol. 14, no. 1, pp. 103-108, 2003.

[10] D. L. Tiemann, "Nature's toy train, the railroad worm," National Geographic, vol. 138, no. 1, pp. 56-67, 1970.

[11] R. C. Halverson, J. F. Case, J. Buck, and D. Tiemann, "Control of luminescence in phengodid beetles," Journal of Insect Physiology, vol. 19, no. 6, pp. 1327-1339, 1973.

[12] V. R. Viviani and E. J. H. Bechara, "Bioluminescence and biological aspects of Brazilian railroad-worms (Coleoptera: Phengodidae)," Annals of the Entomological Society of America, vol. 90, no. 3, pp. 389-398, 1997.

[13] C. Costa, S. A. Vanin, S. A. Casari, and V. R. Viviani, "Larvae of Neotropical Coleoptera. XXVII. Phrixothrix hirtus: immatures, neotenic female, adult male and bionomic data (Phengodidae, Phengodinae, Coleoptera)," Iheringia, vol. 86, pp. 9-28, 1999.

[14] S. A. Casari-Chen and C. Costa, "Larvas de Coleoptera da Região Neotropical XV. Revisao dos Pyrophorini (Elateridae, Pyrophorinae)," Revista Brasileira de Entomologia, vol. 30, no. 2, pp. 323-357, 1986.

[15] J. Sivinski, "The nature and possible functions of luminescence in Coleoptera larvae," Coleopterists Bulletin, vol. 35, no. 2, pp. 167-179, 1981.

[16] J. E. Lloyd, "Insect bioluminescence," in Bioluminescence in Action, P. J. Herring, Ed., pp. 241-272, Academic Press, London, UK, 1978.

[17] C. Costa, "Pyrearinus termitilluminans, sp. n., with description of the immature stages (Coleoptera, Elateridae, Pyrophorini)," Revista Brasileira de Zoologia, vol. 1, no. 1, pp. 23-30, 1982.

[18] K. H. Redford, "Prey attraction as a possible function of bioluminescence in the larvae of Pyrearinus termitilluminans (Coleoptera: Elateridae)," Revista Brasileira de Zoologia, vol. 1, no. 1, pp. 31-34, 1982.

[19] M. I. Migliaccio, E. J. H. Bechara, C. Costa, S. A. Vanin, and P. Colepicolo-Neto, "Cupinzeiros luminescentes," Ciência Hoje, vol. 16, no. 3, pp. 92-93, 1985.

[20] C. Costa, "Systematics and evolution of the tribes Pyrophorini and Heligmini with description of Campyloxeninae, a new subfamily," Arquivos de Zoologia, vol. 26, no. 2, pp. 49-190, 1975.

[21] E. J. H. Bechara, "Luminescent elaterid beetles: biochemical, biological and ecological aspects," in Advances in Oxygenated Process, A. L. Baumstark, Ed., vol. 1, pp. 123-178, JAI Press, London, UK, 1988.

[22] C. Costa, "Genus Pyrophorus. 3. Life-history, larva and pupa of Pyrophorus punctatissimus Blanchard (Col., Elateridae)," Papéis Avulsos de Zoologia, vol. 23, no. 8, pp. 69-76, 1970. 
[23] F. L. N. de Caumat de Laporte Castelnau, Expedition dans les parties centrales de l'Amerique du Sud, de Rio de Janeiro à Lima, et de Lima au Para. Executee par ordre du Gouvernement Francais pendant les annes 1843 à 1847, Vol. 2. Histoire du Voyage, P. Bertrand, Paris, France, 1980.

[24] F. Knab, "Ant nests," Entomological News, vol. 6, no. 1, pp. 15$16,1895$.

[25] F. Knab, "Luminous termite hills," Science, vol. 30, no. 773, pp. 574-575, 1909.

[26] H. H. Smith, Brazil, the Amazons and the Coast, C. Scribner's Sons, New York, NY, USA, 1879.

[27] J. C. Branner, "Geologic work of ants in tropical America," Bulletin of the Geological Society of America, vol. 21, no. 4, pp. 449-496, 1910.

[28] A. Neiva and B. Penna, "Viajem scientifica pelo norte da Bahia, sudoeste de Pernambuco, sul do Piauhi e de norte a sul de Goiaz," Memorias do Instituto Oswaldo Cruz, vol. 8, no. 3, pp. 74-224, 1916.

[29] E. N. Harvey, Bioluminescence, Academic Press, New York, NY, USA, 1952.

[30] F. Schaller, "On the glowing and preying behaviour of lampyrid and pyrophorine larvae (Coleoptera: Lampyridae, Elateridae): an open subject for future research in Amazonia," Amazoniana, vol. 16, no. 3-4, pp. 483-486, 2001.

[31] F. Schaller, "Erratum: On the glowing and preying behaviour of lampyrid and pyrophorine larvae (Coleoptera: Lampyridae, Elateridae): An open subject for future research in Amazonian-Scientific note by F. Schaller," Amazoniana, vol. 18, no. 3-4, p. 405, 2005.

[32] C. Costa, "Sistemática e biologia de Pyrearinus Costa, 1975 (Coleoptera, Elateridae)," Arquivos de Zoologia, vol. 29, no. 4, pp. 185-236, 1978.

[33] J. C. Branner, "The luminosity of termites," Science, vol. 31, no. 784 , pp. 24-25, 1910.

[34] J. C. Branner, "The luminosity of termites," Science, vol. 32, no. 819 , p. $342,1910$.

[35] J. S. da Fonseca, Viagem ao redor do Brasil, vol. 2, Rio de Janeiro, Brazil, 1880-1881.

[36] J. S. da Fonseca and P. de Almeida, Voyage autour du Bresil. Édition pour les américanistes, Librairie A. Lavignasse Filho \& C, Rio de Janeiro, Brazil, 1899.

[37] K. Lenko and N. Papavero, Insetos no folclore, Plêiade/FAPESP, Sao Paulo, Brazil, 2nd edition, 1996.

[38] A. Marien, Era um poaieiro (novela matogrossense), Livraria Tecnica Editora, Sao Paulo, Brazil, 1946.

[39] L. S. Otero, Gente de rancho. Contos goianos, Bolsa de Publicacoes "Hugo de Carvalho Ramos", Goiânia, Brazil, 1954.

[40] P. Colepicolo-Neto, C. Costa, and E. J. H. Bechara, "Brazilian species of luminescent Elateridae. Luciferin identification and bioluminescence spectra," Insect Biochemistry, vol. 16, no. 5, pp. 803-810, 1986.

[41] C. 1. Girard and M. Lamotte, "L'entomofaune des termitieres mortes de Macrotermes: les traits generaux du peuplement," Bulletin de la Societe Zoologique de France, vol. 115, no. 4, pp. 355-366, 1990.

[42] A. V. Evans and C. L. Bellamy, An Inordinate Fondness for Beetles, University of California Press, Los Angeles, Calif, USA, 2000.

[43] C. Costa and S. A. Casari-Chen, "Larvae of neotropical Coleoptera. VIII. Elateridae: Agrypninae, Elaterinae and Physorhininae," Revista Brasileira de Entomologia, vol. 28, no. 3, pp. 315-328, 1984.

[44] W. W. Froggatt, "Entomological notes: a remarkable beetle (Tetralobius (sic) fortnumi Hope)," Agricultural Gazette of New South Wales, vol. 28, pp. 891-895, 1917.
[45] D. Carpenter, "The larva and cocoon of the Elaterid beetle Tetralobus flabelicornis L. from Uganda," Proceedings of the Entomological Society of London, vol. 3, p. 73, 1929.

[46] C. Costa and C. R. V. Fonseca, "Larvae of Neotropical Coleoptera. XIII. Passalidae, Passalinae," Revista Brasileira de Entomologia, vol. 30, no. 1, pp. 57-78, 1986.

[47] S. A. Vanin, C. Costa, and L. R. Fontes, "Larvae of Neotropical Coleoptera. VI. Scarabaeidae, Dynastinae, Phileurini," Papeis Avulsos de Zoologia, vol. 35, no. 5, pp. 55-72, 1983.

[48] H. Luederwaldt, "Quatro lamellicorneos termitophilos," Revista Museu Paulista, vol. 8, pp. 405-413, 1911.

[49] J. F. Lawrence, D. H. Kistner, and J. M. Pasteels, "A new genus and three new species of termitophilous Aderidae (Coleoptera) from Australia, Papua New Guinea and the Philippines, with notes on their biology," Invertebrate Taxonomy, vol. 4, no. 3, pp. 643-654, 1990.

[50] D. H. Kistner, "The biology of termitophiles," in Biology of Termites, K. Krishna and F. M. Weesner, Eds., vol. 1, pp. 525537, Academic Press, New York, NY, USA, 1969.

[51] D. H. Kistner, "Social and evolutionary significance of social insect symbionts," in Social Insects, H. R. Hermann, Ed., vol. 1, pp. 339-413, Academic Press, New York, NY, USA, 1979.

[52] D. H. Kistner, "The social insect's bestiary," in Social Insects, H. R. Hermann, Ed., vol. 3, pp. 1-244, Academic Press, New York, NY, USA, 1982.

[53] R. L. Araújo, “Termite of the neotropical region," in Biology of Termites, K. Krishna and F. M. Weesner, Eds., vol. 2, pp. 527576, Academic Press, New York, NY, USA, 1970.

[54] K. Berg, "Termitariophilie," Comunicaciones del Museo Nacional de Buenos Aires, vol. 1, no. 6, pp. 212-215, 1990. 

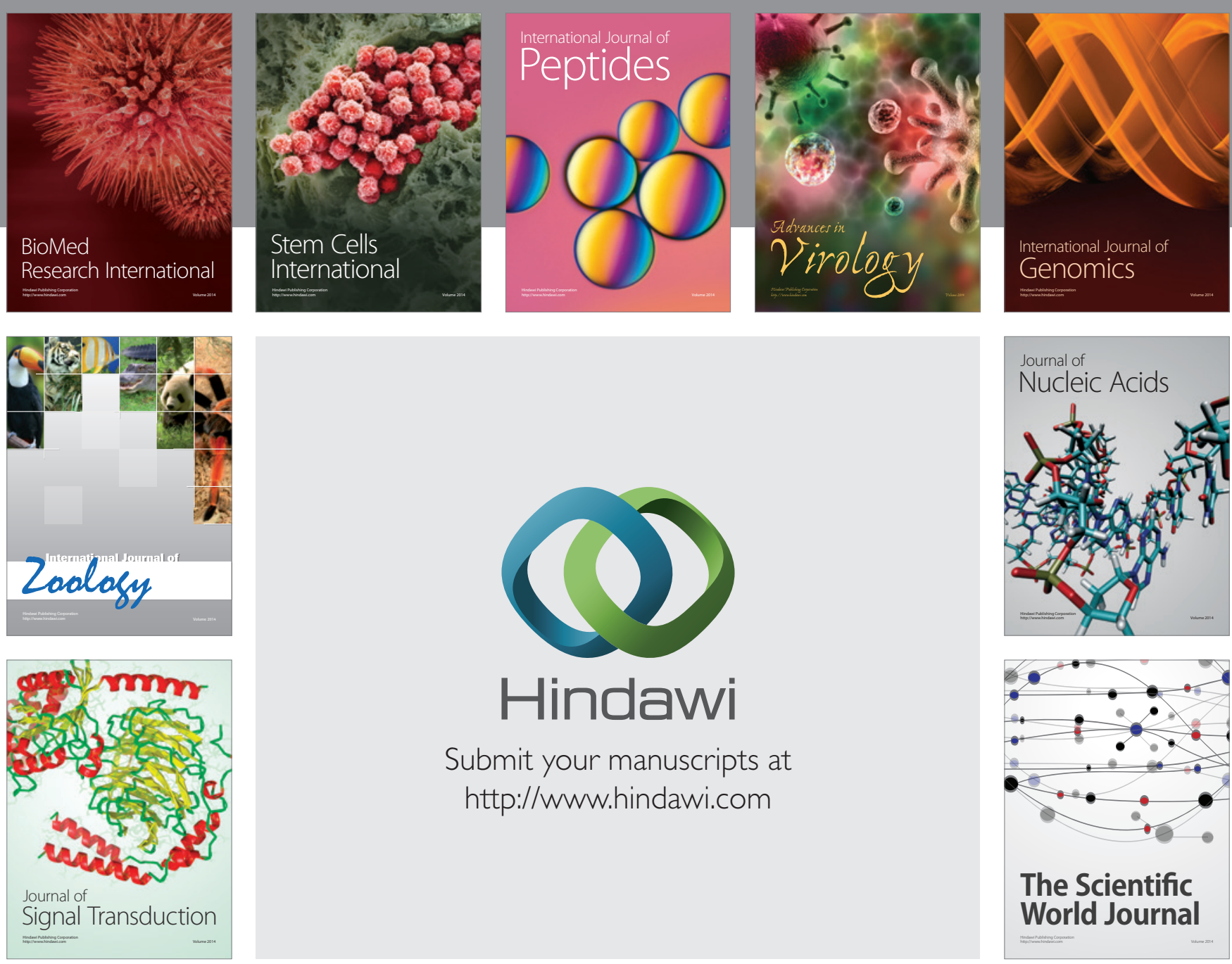

Submit your manuscripts at

http://www.hindawi.com
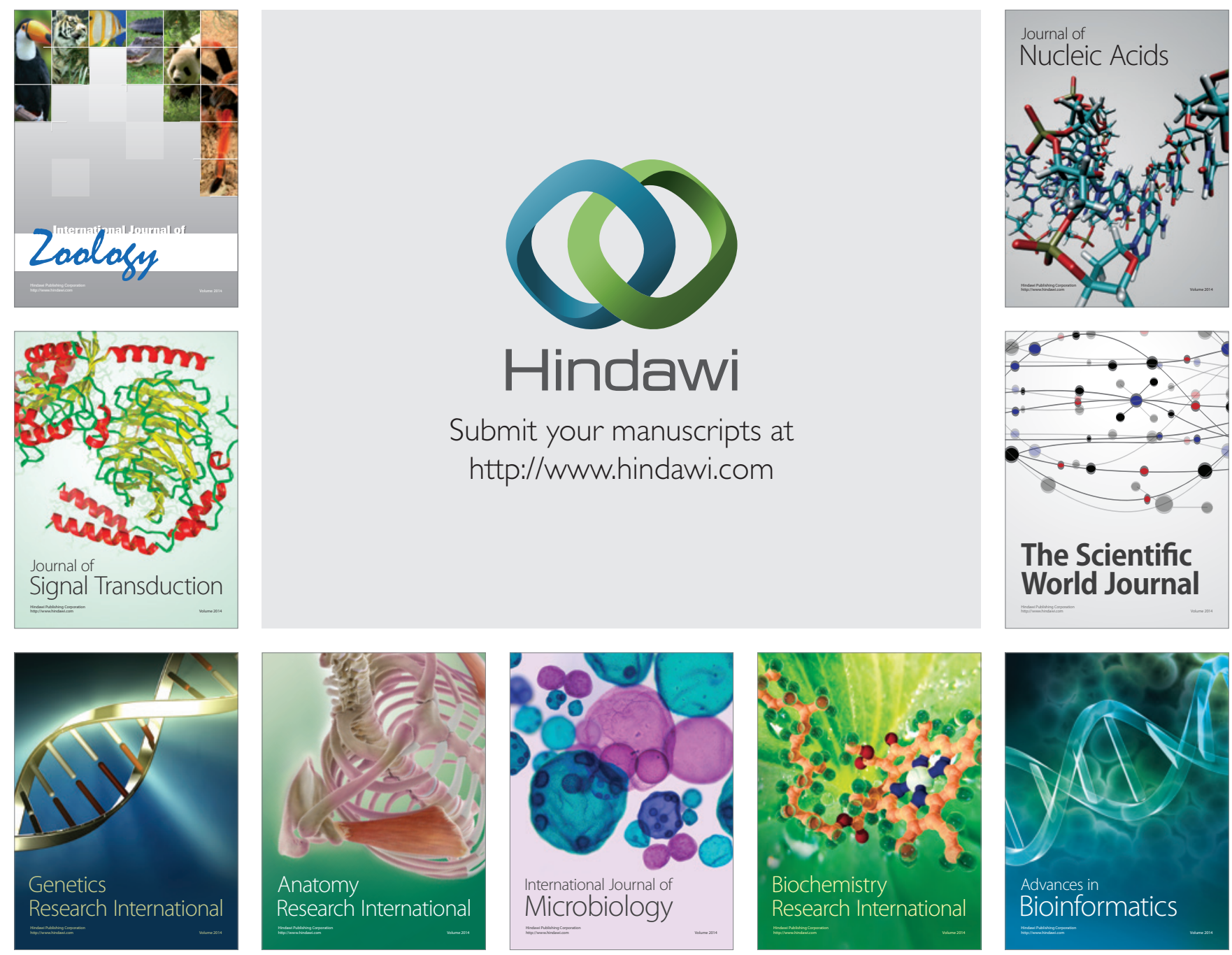

The Scientific World Journal
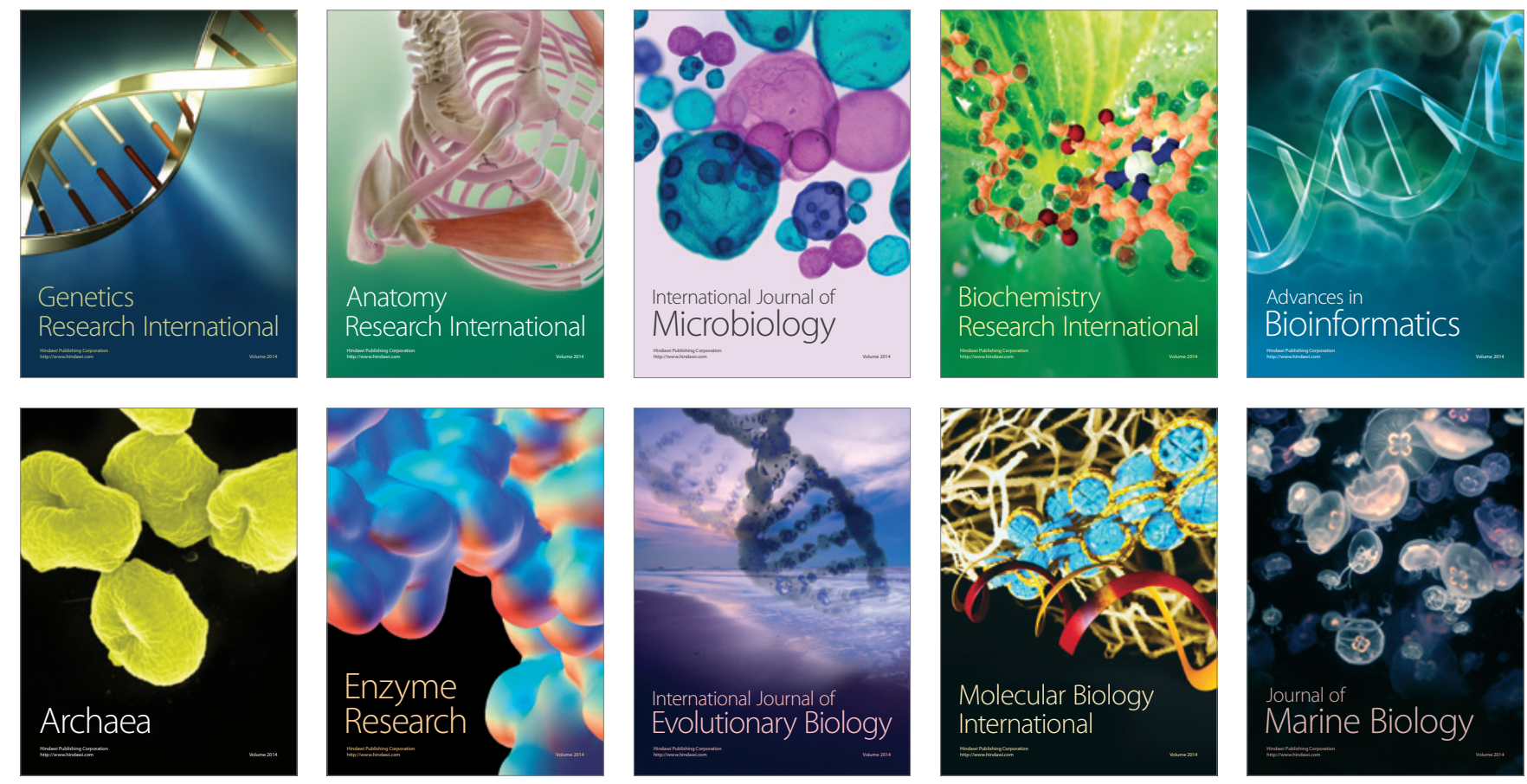